\title{
Anti-CD37 Monoclonal Antibody BI 836826
}

National Cancer Institute

\section{Source}

National Cancer Institute. Anti-CD37 Monoclonal Antibody BI 836826. NCI Thesaurus.

Code C122833.

An Fc-engineered, chimeric immunog lobulin (Ig) G1 monoclonal antibody ag ainst the tumor-associated antigen (TAA) CD37, with potential antineoplastic activity. Upon administration, the anti-CD37 monoclonal antibody BI 836826 both activates the immune system to induce an antibody-dependent cell-mediated cytotoxicity (ADCC) against CD37-overexpressing tumor cells and induces apoptosis in these tumor cells. BI 836826 is Fc-engineered to improve ADCC activity and enhance affinity for the receptor Fc-gamma-RIIla, which is expressed on human natural killer (NK) cells. CD37, a member of the tetraspanin superfamily of cell surface antigens, is overexpressed on a variety of cancer cell types and plays a key role in tumor cell proliferation. 